\title{
Linguistic Enfranchisement
}

\author{
Zane Goebel* \\ La Trobe University, Melbourne \\ z.goebel@latrobe.edu.au \\ Anthony Jukes \\ University of the South Pacific, Fiji \\ anthony.jukes@usp.ac.fj \\ Izak Morin \\ La Trobe University, Melbourne \\ imorin@students.latrobe.edu.au
}

\begin{abstract}
Drawing on sociolinguistic research, this article introduces the concept of 'linguistic enfranchisement' (LE). Large one-to-many participation frameworks, such as schooling, mass media, and bureaucratic institutions, help populations to comprehend a particular variety of language by providing access to written and spoken forms of an emerging 'standard' language of the nation. We refer to this process as LE, while pointing out that LE can be seen as a product. This is so because $L E$ also refers to the linguistic forms that are modelled as a language within these nation-building infrastructures. Nation-building infrastructures also engender LE in other languages, which can ultimately come into competition with the language of the nation-state. We refer to this as 'latent enfranchisement', with 'latent' being used to indicate potential LE. In theorizing LE, we focus on the languages used in political campaign posters from three parts of Indonesia: West Java, Papua, and Manado.
\end{abstract}

* This article has benefited from the generous and engaging feedback that we received from two anonymous reviewers, Freek Colombijn and Klarijn Loven. All omissions, errors, misinterpretations, and faults, however, are our responsibility.

(C) ZANE GOEBEL, ANTHONY JUKES AND IZAK MORIN, 2017 | DOI: 10.1163/22134379-17301006

This is an open access article distributed under the terms of the prevailing CC-BY-NC license at the time of publication. 


\section{Keywords}

linguistic landscapes - linguistic enfranchisement - Indonesia - political campaign political signage - semiotics

\section{Introduction}

This article introduces and theorizes the concept of linguistic enfranchisement (LE) by focusing on a particular type of language use: that found on signage. In paying close attention to how this signage can be linked to complex histories of practices on several territorial scales, we are especially interested in exploring what this signage can tell us about LE. LE can be thought of as a process, product, and object that creates and projects its audience. In terms of process, we refer to how infrastructures, such as schools and the mass media, help to circulate and standardize a language among a certain population. In terms of $\mathrm{LE}$ as a product, we refer to the outcome of such processes, which include a population's ability to recognize and use this language. As an object, LE refers to the linguistic and semiotic forms that are recognized as belonging to the language of the nation. We contrast LE with latent enfranchisement, whereby a key enabling infrastructure of LE is not yet in place, such as schooling practices that teach a particular language or deliver content via a particular language.

Our empirical focus will be the language used in political campaign posters from various parts of Indonesia. This usage contrasts quite remarkably with the semiotic format of campaign material from two decades earlier, where colours and symbols were the main components of campaign signage rather than linguistic form. Change seems to be a defining feature of Indonesia since President Soeharto's resignation in May 1998. Some of the most well-known changes include: the relaxation of media censorship; democratization of the political process; decentralization of governance, political structures, and fiscal responsibility; rapid territorial fragmentation; inter-ethnic and inter-religious conflicts; increases in the value of ethnicity and ethnic languages; and ongoing urbanization that has increased inter-ethnic contact and, with it, the need for social harmony (Aspinall, 2011; Aspinall \& Mietzner, 2010; Bünte \& Ufen, 2009; Cole, 2016; Davidson \& Henley, 2007; Donzelli, 2016; Goebel, 2015; Harr, 2016; Hedman, 2008; Kitley, 2000; Kurniasih, 2016). We will argue that signage can give us insights into change too, especially the stage at which a population and their language has become enfranchised.

We start by looking at the relationships between language and enfranchisement before moving to how we can empirically investigate these relationships 
through a sociolinguistic approach which focuses on linguistic landscapes. We then present our analysis of six examples of political campaign signage from West Java, Papua, and North Sulawesi. We conclude by pointing out how the concept of linguistic enfranchisement might enhance collaboration across disciplines, while pointing to some potential areas for future research.

\section{Language and Enfranchisement}

We know that constructing and delivering a standard language via schooling, bureaucracies, and the mass media is key to building a nation-state and creating a sense of pride among its territory and people (Heller, 2011; Heller \& Duchêne, 2012b; Hobsbawm, 1992). We also know that these infrastructures of nation-building also operate at smaller scales, helping to create and reproduce ethnolinguistic and other groups - often imagined to reside in a particular territory - within the boundaries of a nation-state (Gal, 2012; Goebel, 2015; Moore, 2011; Pietikäinen \& Kelly-Holmes, 2013). Nation-building efforts that involve the standardization and spread of a national language also create inequalities, especially for those who speak other languages and do not have access to the domains where they can learn the standard form (Blommaert, 2010; Bourdieu, 1991; Heller, 2011; Heller, Bell, Daveluy, McLaughlin, \& Noel, 2015).

Blommaert $(2010,2013)$ points out that these processes help create different centres of normativity around language practices. These centres, it is argued, are hierarchically organized into what Blommaert (2010) calls 'orders of indexicality'. Within these orders, the national language typically sits at the top of the hierarchy, while other varieties of the national language and other languages sit lower down the hierarchy. While it is the large one-to-many participation frameworks of school classrooms, bureaucracies, and the media, and the complex responses to the forms of language used within them that help produce and circulate or imitate 'standard languages' (Agha, 2007; Goebel, 2015, 2016; Inoue, 2006; Urban, 2001), this hierarchization process has its genesis in much smaller-scale activities. The case of French in Canada is instructive in this regard.

In Canada, economic inequality between English and French speakers resulted in a series of small-scale movements lobbying for French language rights (Heller, 2011). Small-scale but fragmented success resulted in the incremental introduction of bilingual schooling and language policies relating to the conduct of social life in government offices and businesses (Heller, 2011). Over time, these small-scale entities became aware of other such entities, 
which enabled larger-scale lobbying and language rights activities. Thus, a fragmented, small-scale phenomenon about language rights was imitated (that is, received uptake through imprecise replication) and became a larger one, which helped increase the social value of a particular variety of French spoken by a particular segment of French Canadian society. In doing so, a particular variety of French was becoming associated with a particular group of people and a particular territory. The end result of these processes was pride in Canadian French, Canadian French-ness, and the territories that were populated by these social types, or, more succinctly, nationalism of the type described by Hobsbawm (1992). This process led to calls for autonomy, with decentralization a common solution in Canada, as elsewhere in the world (Hobsbawm, 1992: 187).

While participation in education provides access to a state-authorized language (for instance, Canadian French), and, with it, enfranchisement for those who can recognize and use it, we also know that schools provide and create multiple models of language and language users which can become normative in certain settings. To again draw on the French Canadian example, Heller and colleagues (2015) point out that English speakers who went to academically oriented schools (that is, ones that taught languages, maths, physics, chemistry, and so on) often took French as a subject and subsequently got the relatively well-paid and scarce white-collar jobs that required the type of French that they were taught in school. On the other hand, those who enrolled in vocationally oriented schools often didn't take French as a subject and, as a consequence, were rarely able to model the type of French required to get these white-collar jobs, even when they were native speakers of French. In this way, schools, as infrastructures for nation-building, can inadvertently serve to create and reproduce multiple centres of ethnolinguistic normativity: in this case, those who can imitate school French and those who cannot. This type of ethnolinguistic fragmentation has similarities with class-type stratification and could be meaningfully discussed with regard to class in Bourdieuian terms (Bourdieu, 1984; Bourdieu \& Passeron, 1977).

Class-type stratification is not the only form of fragmentation engendered by schools. Time stratifies, too. Those who grew up in one era may have very different language repertoires and ideas about what constitutes a normative repertoire than those socialized in a different era (Rampton, 2011). Studies of language shift and language change demonstrate that these shifts may initially be caused by nation-building exercises, which increase the value of the national language while decreasing the value of the local language as a language of social and economic mobility (e.g. Errington, 1998; Jukes, 2010; Kuipers, 1998). As regimes change, so does support for different sets of languages, sometimes filtering into the school community and ultimately providing a further way in 
which nation-building activities create fragmentation (Goebel, Cole, \& Manns, 2016; Kurniasih, 2007; Sudarkam Mertono, 2014).

Initiatives from educators and bureaucrats within nation-building infrastructures, such as education departments, also play a role in stratification. For instance, consider the moves in the us and Australia, where there has been implementation of phonetic approaches to language and literacy and wholelanguage approaches (Cope \& Kalantzis, 200o). The implementation of each approach at different times by different governments with different ideological positions helps to produce new models of language use and users. Within school themselves, fragmentary forces are also in play. Students seek out those who are sociolinguistically the same as they are. These processes engender the imitation of old language practices, ways of dress, and so on, and the creation of new ones which act as emblems of membership to a community of practice (e.g. Bucholtz, 1999; Eckert, 200o; Rampton, 1995, 2006). These emblems enable students to distinguish themselves from others, and for others to recognize them as different.

Ultimately, schooling involves cohorts of people separated by time and space, creating multiple local groups who, through their uptake and reuse of the linguistic fragments in circulation and through the pursuit of sameness and difference, tend to create new local varieties that are perceived to be the local standard by a particular community of practice. The emergence of multiple standards - that is, fragmentation - is thus a logical and unavoidable outcome of nation-building projects at whatever stage. This process creates multiple centres of normativity, where members of these centres claim to use the standard language and be exemplars of such use. In short, the unintended outcome of nation-building processes can be, and often is, a more complex order of indexicality, often with one order nested within another.

The existence of these orders of indexicality also enables people who have been socialized in one order to make distinctions between themselves and those who have different trajectories of socialization. That is, they can hear and evaluate the normalness of other linguistic practices in relation to those with which they are familiar. In other words, they engage in distinction and boundary-making (Barth, 1969; Bourdieu, 1984). It is a process that also creates similar conditions to those found in the type of language rights movements noted earlier. In this sense, any new centre of normativity has the potential of becoming an object of, and medium for, rights movements, which can enable the language in question to be used in political activities in the public sphere; that is, this situation produces 'latent enfranchisement'. Within the linguistic landscape, political campaign signage is one place where we can look for signs of enfranchisement. 


\section{Linguistic Landscapes}

Scholars who study linguistic landscapes seek to understand the meanings of bits of language that are inscribed into the landscape and what they can tell us about society and change more generally. Inscription can take many forms and can include street signs, shop signage, graffiti, and signs that are mobile, such as inscriptions on the side of vehicles and litter bins (Blommaert, 2013). The study of linguistic landscapes emerged as a field in the late 1990s. Since then, it has gathered momentum through the work of Scollon and Scollon (2003), Stroud and Mpendukana (2009), Blommaert (2013), and others. Contemporary work on linguistic landscapes aligns with semiotic analyses of materiality (e.g. Keane, 1999; 2003) in that it highlights the need to understand the relationships that exist between the semiotic configuration of signs, including their material make-up; between sets of signage (for instance, the degree of imitation between signs); between signage and space; and between signage and social, economic, political, and historical circumstances.

These scholars all point out that multilingual signage can be authorized or not, and that the placement of these signs and the ordering of the languages on them changes as social change occurs (Blommaert, 2013; Scollon \& Scollon, 2003; Stroud \& Mpendukana, 2009). This ordering often has intimate relationships with orders of indexicality. These scholars' works also demonstrate how the distribution of authorized and non-authorized signs can be mapped onto socio-economic concerns relating to necessity and luxury, and to human migration (Blommaert 2013; Scollon and Scollon 2003; Stroud and Mpendukana 2009). Blommaert (2013), in particular, invites us to see signage as an initial indicator of change. For example, the appearance of temporary signs in the form of handwritten 'room for rent' advertisements can be indicative of new populations residing in an area. These signs are written for, and target, or in sociolinguistics speak, 'select', a particular audience who can read that language; that is, they engender 'indexical selectivity'.

Blommaert (2013), Scollon and Scollon (2003), and Stroud and Mpendukana (2009) also point out that the material form of these signs (for instance, whether it is handwritten, a glossy print, or a complex billboard) also provides clues as to where those who write and read these signs sit in the social, economic, political, and linguistic hierarchy. Typically, the more expensive sign formats point to much more complicated relationships between the producers and consumers of signs and space. For example, handwritten signs are typically produced and consumed locally and require limited resources, while road regulation signs are a culmination of a complex set of interactions between national and regional governments, local councils, road transport authorities, 
media (for instance, in the case of reports about a dangerous road section that needs better signage), designers, factories that produce the sign, and so on.

Finally, the work described above aligns with other work in sociolinguistics, especially work that points to the tensions between the authorized languages of the nation-state and situations where the nation-state has less power to police language use as languages become linked to commercial activities (Heller, 2011; Heller et al., 2015; Heller \& Duchêne, 2012a; Heller, Pujolar, \& Duchêne, 2014). In the Indonesian context, we have seen that local ethnic languages have become commodified on television as broadcasters responded to market deregulation and sought ways to increase their audiences (Goebel, 2008; Loven, 2008; Rachmah, 2006; Sen \& Hill, 2000).

This commodification of language on television has modelled particular ideologies about language, including language as a mixed phenomenon (Goebel, 2015). These 'semiotic ideologies' (Keane, 2003: 419) about language - that is, what signs are recognized and authorized as constituting a language-sit in tension with language policy at the level of the nation-state, which sees language as a unitary and unmixed entity. At the same time, representations of mixed languages also potentially select multiple audiences (Cole, 2016). In the following analysis of signage from different parts of Indonesia, we will draw these dimensions (authorization, mobility, change, indexical selectivity, and hierarchies) together, in order to explore what these signs can tell us about enfranchisement.

\section{Linguistic Enfranchisement in Contemporary Indonesia}

The material we present here contrasts quite remarkably with campaign material from two decades ago. The earlier material relied upon the recognition of colour and symbols rather than linguistic form. Among this material was that belonging to the government party, Golkar (short for golongan karya, literally 'Functional Groups'), which used a symbol taken from the set of symbols that made up the national ideology, Pancasila. This symbol was always placed in the centre and on a yellow background. Where there was any text at all, what was typically inscribed was the word 'Golkar' in a small font below the large symbol. The two remaining parties, which were largely allowed to exist as symbols of democratic competition, included Partai Demokrasi Indonesia (Indonesian Democratic Party, or PDI) and Partai Persatuan Pembangunan (United Development Party, or PPP). The semiotic configuration of their campaign banners was similar to that of Golkar, with the symbol of a buffalo head placed in the 
middle of a red background on PDI material, and of a star centred in the middle of a green background for PPP. Like the Golkar material, there was little use of linguistic forms and the forms that were used typically only included the full or shortened name of the party. These forms were commonly placed underneath the symbol. In the 1997 election campaign in Semarang (Central Java), this signage was often made up of cloth that was flag-like and located at the side of the road, or was draped as a large banner on moving trucks full of 'supporters' dressed in party colours.

In this section we look at more contemporary examples of campaign signage within the linguistic landscape of Indonesia, to explore what these signs can tell us about enfranchisement. The first example is on the village level and selects a particular type of local public, in this case the section of the population that can recognize and potentially speak Sundanese. It provides insights into past and potential change. Our second and third examples move to the provincial and city level respectively. As with the first example, these also provide insight into language hierarchies, along with past and potential change. Examples four to six show both the provincial scale and a city scale which is largely symbolic, or even tokenistic, through the use of an endangered local language (as in Example 6). All examples also engender distinction on the national level via their links with the language of the nation-state, Indonesian.

Figure 1 depicts a poster used in a political contest in late 2014 in the city of Cirebon (West Java). Goebel photographed this poster in October 2014, when it was placed on the side of the main road of the main shopping area of Ciledug, which is a small town located to the southeast of Cirebon. This area is a linguistic border inhabited by Sundanese and Javanese speakers. In this campaign poster for seats in the regional and provincial senates we find a number of languages, including Indonesianized Arabic, Indonesian, and Sundanese. Note that the Sundanese portion of the text, Wargi Urang Sadaya (literally, 'family us all') is at the top and in the centre, and forms the largest piece of text; it is followed by the smaller Indonesianized Arabic phrase Insya Allah Amanah (God willing [we] will get a mandate). When read in relation to the portraits and the use of local emblems of Cirebon, including batik (left picture), fishing boats (middle picture), and ocean produce (right picture), the meaning of the Sundanese text more closely resembles 'We are part of your local family'. Note, too, that the material format is a mass-produced poster that is not made of long-lasting material. The material thus also points to the ephemerality of this semiotic configuration.

So what can we learn from this poster? First, we can say that the use of faces and names and the space that the politicians take up on this poster 


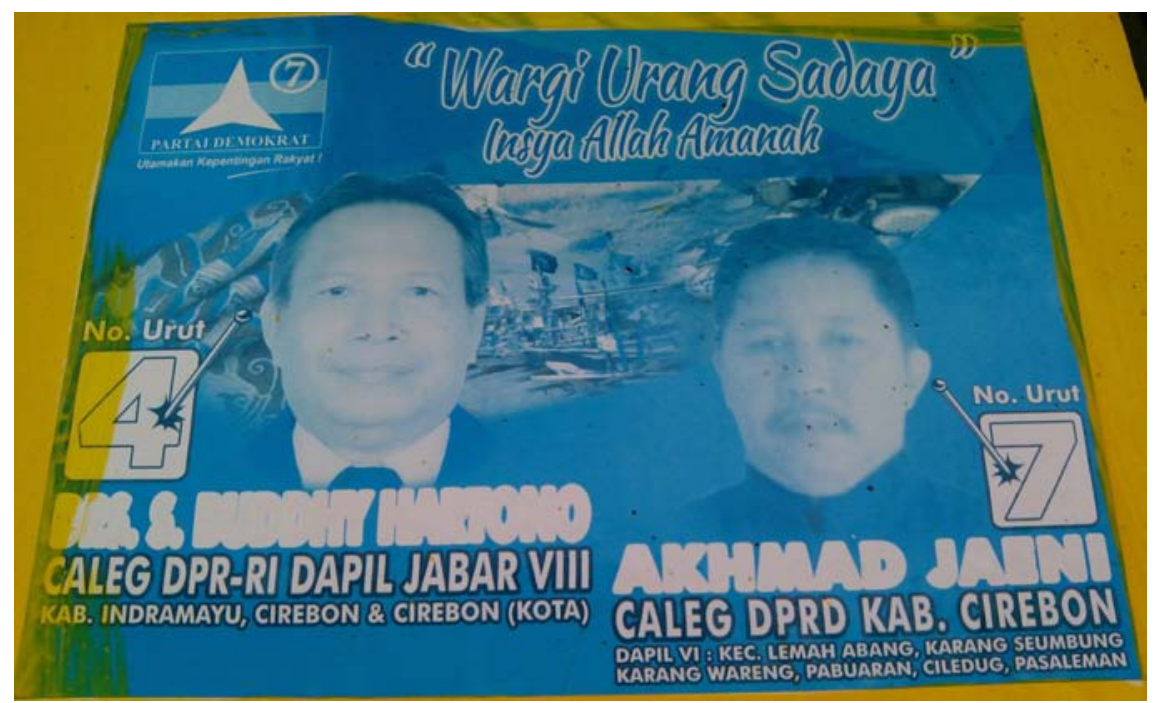

FIGURE 1 A local language for a local constituent

suggests that personalities are more important than parties. In this case the party itself, the Partai Demokrat (Democratic Party), is represented by a small symbol in the top left corner. Just as importantly, the poster targets those who can read Sundanese and those who are likely to be Muslim. Thus, we can add that those involved in the sign's production and placement imagine that the inhabitants of the immediate surroundings and passers-by will most likely be able to understand Sundanese. If we look at the linguistic abilities of the population in the space surrounding this sign we find that this campaign poster is located in a multilingual zone. This zone is populated by Javanese and Sundanese speakers - many of whom speak both languages - as well as migrants from other areas of Indonesia.

If we take a historical view of signage and language policy prior to 1998, we can also say that Figure 1 contrasts with earlier signage, which only used Indonesian, even though Sundanese, Javanese, and Arabic were authorized languages that were taught in schools and could be found on the radio and on television (Dardjowidjojo, 1998; Goebel, 2015; Kitley, 2000; Loven, 2008; Moriyama, 2005, 2012; Nababan, 1991). Part of the reason for these changes in signage practices relates to increases in the value of localness that occurred as part of the decentralization process (e.g. Aspinall, 2011; Cole, 2016; Djenar, 2016; Donzelli, 2016; Hariyadi, Shodiq, \& Restuadhi, 2015; Harr, 2016; Henley \& Davidson, 2007; Moriyama, 2012).

Decentralization plays out in many social domains and on several scales, including in the ongoing implementation of language policies by the central 


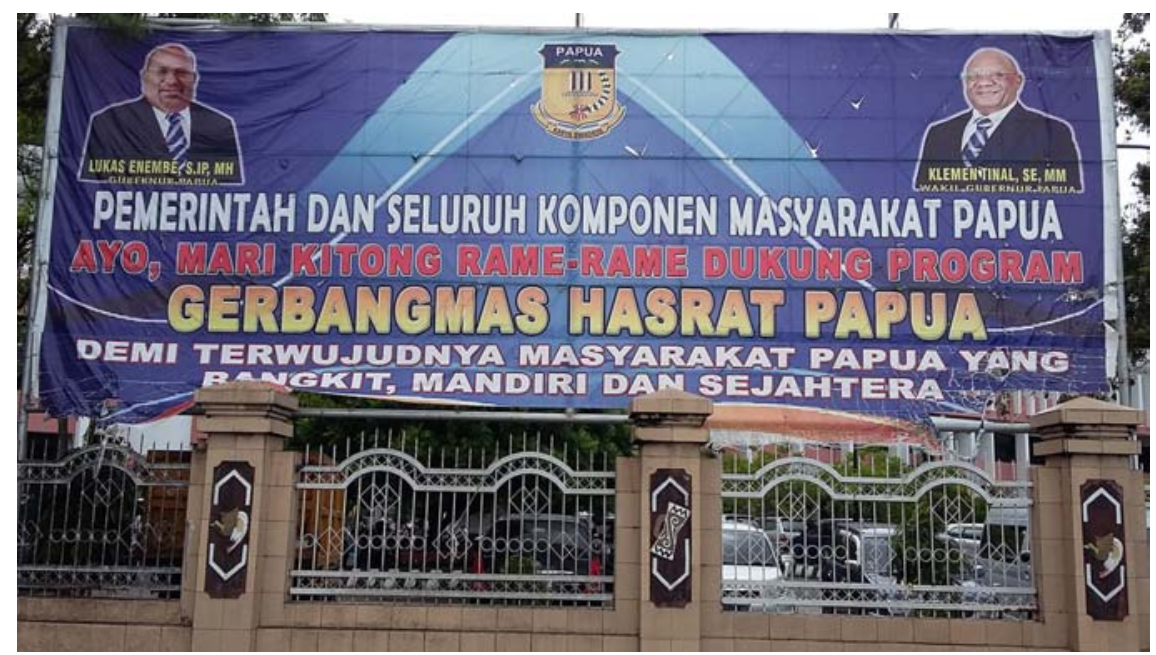

FIGURE 2 Evidence of an emerging authorized language on the provincial scale?

government, ${ }^{1}$ the provincial government, ${ }^{2}$ and the Cirebon city government. ${ }^{3}$ The use of Sundanese in the campaign signage we have looked at above suggests uptake of these regulations to the extent that Sundanese sits at the top of the local language hierarchy in the imaginations of those who produced the signage in Figure 1. Viewed in terms of linguistic enfranchisement, we can say that although there has been a linguistically enfranchised population in this area at least since the mid-199os, Sundanese seems to have gained value in the public sphere of political campaigning much more recently.

Figure 2 was photographed in April 2015 by Morin. It is a cloth banner with an invitation from the governor and vice governor of Papua for the reader to support a new form of regional autonomy being introduced in Papua. Note the use of fragments of Papuan Malay (PM): kitong (we) and rame-rame (together). Note, too, that in contrast to Figure 1 these fragments of the local language are simply inserted into the Indonesian text. This suggests four things. First, those

1 (e.g. Menteri Dalam Negeri [Domestic Affairs Ministry], Regulation No. 40/2007, Articles 1 and 2)

2 See, for instance, Regulation no. 69/2013 tentang Pembelajaran Muatan Lokal Bahasa dan Sastra Daerah pada Jenjang Satuan Pendidikan Dasar dan Menengah, Articles 2-4; and Regulation no. 14/2014, Perda Provinisi Jawa Barat tentang Perubahan atas Peraturan Daerah Propinsi Jawa Barat nomor 5 tahun 2003 tentang Pemiliharaan Bahasa, Sastra dan Aksara Daerah, Article 3, 7, and $7 \mathrm{~b}$.

3 Regulation no. 6/2007, Perda Kota Cirebon, nomor 6 tahun 2007, tentang Penyelenggaraan Pendidikan di Kota Cirebon, Article 10. 


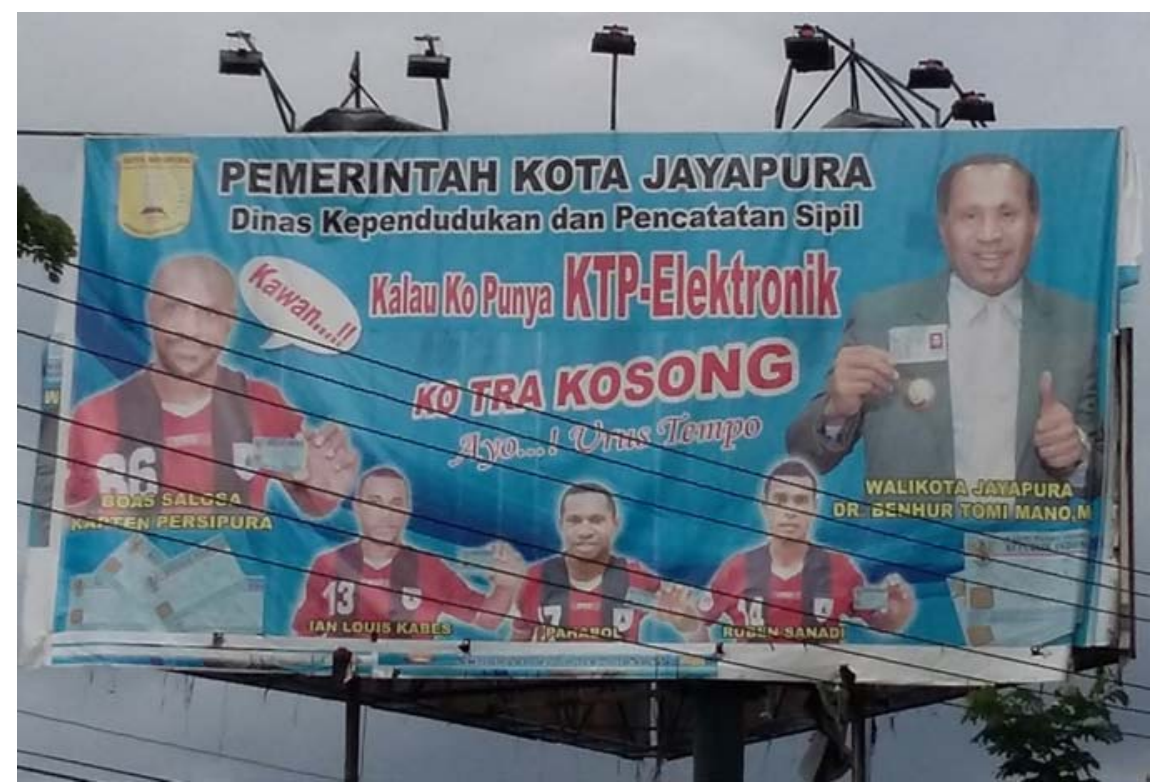

FIGURE 3 Authorization and commodification on the city scale

who inhabit this public space have been imagined to have some familiarity with $\mathrm{PM}$, but much more familiarity with Indonesian.

Second, PM does not have the authorized history that a language such as Sundanese does. If we look at Papuan Malay's history, we can see that although it had an authorized history during the Dutch colonial period, Papua's incorporation into Indonesia in 1969 erased much of this authorization and this has remained the case until very recently (Morin, 2016; Rutherford, 2003: 178). Third, the sign imitates the language hierarchy which has Indonesian at the top and Papuan Malay below (Morin, 2016: 103-105) that has been imposed by a history of language policies. Fourth, although PM is still only used marginally, the material make-up of this banner and its positioning is much more enduring than our poster from Figure 1. This suggests some latent enfranchisement and some longevity for PM on the provincial level.

Figure 3 is a photo taken by Morin in April 2015 in the heart of Jayapura city, Papua. Interestingly, Figure 3 both bears similarities to and differs from Figure 2. We can see that the language hierarchies are the same. Indonesian continues to be inscribed at the top and PM below. Even so, in Figure 3 there is much greater use of $\mathrm{PM}$ and, in a number of cases, PM constitutes a whole sentence, as can be seen on lines 2 and 3 of Extract 1 below, which reproduces some of the text on the sign in Figure 3 (words and phrases in PM have been indicated in bold). 

1 Kalau Ko Punya KTP-Elektronik If you own an electronic ID card
2 Ko tra kosong
3 Ayo ...! Urus tempo
You are somebody
Come [and] get one as quick as you can

We also see that, in contrast to the provincial level in Figure 2, Figure 3 is on the level of a city and authorized by a different level of government, which according to decentralization regulations should have more power in determining local matters, including language policies. For example, the special autonomy law for Papua ${ }^{4}$ and the local governance law ${ }^{5}$ both give the right to local government authorities to determine their local policies, including local language policy. In a sense, the signage in Figure 3 demonstrates the uptake of these policies on the city level, while providing further evidence of latent enfranchisement.

Another interesting aspect of this sign is that in it we can see the intersection of commercial interests-in this case, one of the funded football teams in Papua - with government and language. The football team is positioned as the speaker of the text, or the 'animator', in Goffman's (1981) terms, in Extract 1 , rather than the city, which is the authorizer of the text, and therefore, the 'principle' (Goffman, 1981). The representation of youthful football heroes also selects a particular demographic, including football fans in general and youth in particular. Morin's (2016) work shows that this commodification of PM is not an isolated case, but one that has emerged in a number of social domains since the early part of the new millennium, including films, television broadcasts, and the Internet. While these social domains also represent some of the infrastructures that enfranchised Sundanese (see our discussion of Figure 1) and French (as in our earlier discussion), it would seem that without the reintroduction of this variety in the school system the possibility of PM becoming linguistically enfranchised is limited. Thus, the signage from Papua seems to fit our idea of 'latent enfranchisement'.

Figure 4 is a campaign poster for Johny Runtuwene ('Jonru'), a candidate running for the position of mayor of the city of Tomohon in North Sulawesi, also showing Olly Dondokambey the candidate for governor of the prov-

4 UU Republik Indonesia 21/2001 tentang Otonomi Khusus bagi Provinsi Papua, Article 4 and 58.

5 UU Republik Indonesia 23/2014 tentang Pemerintahan Daerah, Article 17, 22, and 31. 


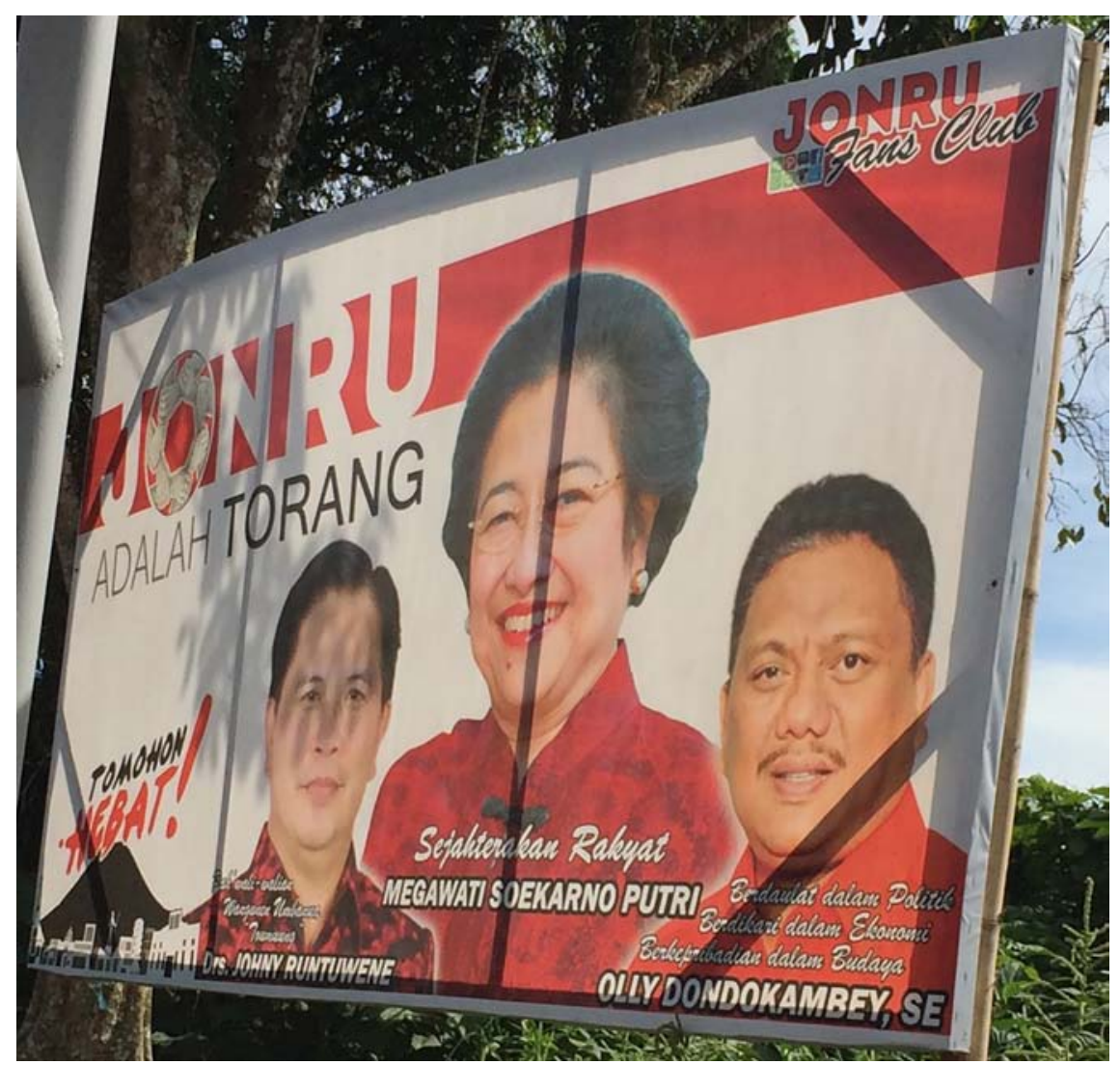

FIGURE $4 \quad$ Selecting a wider audience through mixing

ince. ${ }^{6}$ This sign, photographed by Jukes in June 2015 , is located on the main street in Tomohon.

Figure 4 is notable in several respects. The most obvious is the looming figure in the background, Megawati Soekarnoputri, who was Indonesia's fifth president. While the poster does not explicitly note that Megawati is the leader of the political party PDI-P, the figure of Megawati and the liberal amounts of red presupposes this connection, and is potentially recognizable for anyone raised during the New Order period. In doing so, it selects supporters of this party as potential readers of the sign, while also indexing an interplay of politics at the national and local city levels. Note, too, that if we compare Figure 4 to

6 Tomohon is a city of around 9o,ooo inhabitants located in the highlands of Minahasa, about $25 \mathrm{~km}$ from the provincial capital of Manado. 


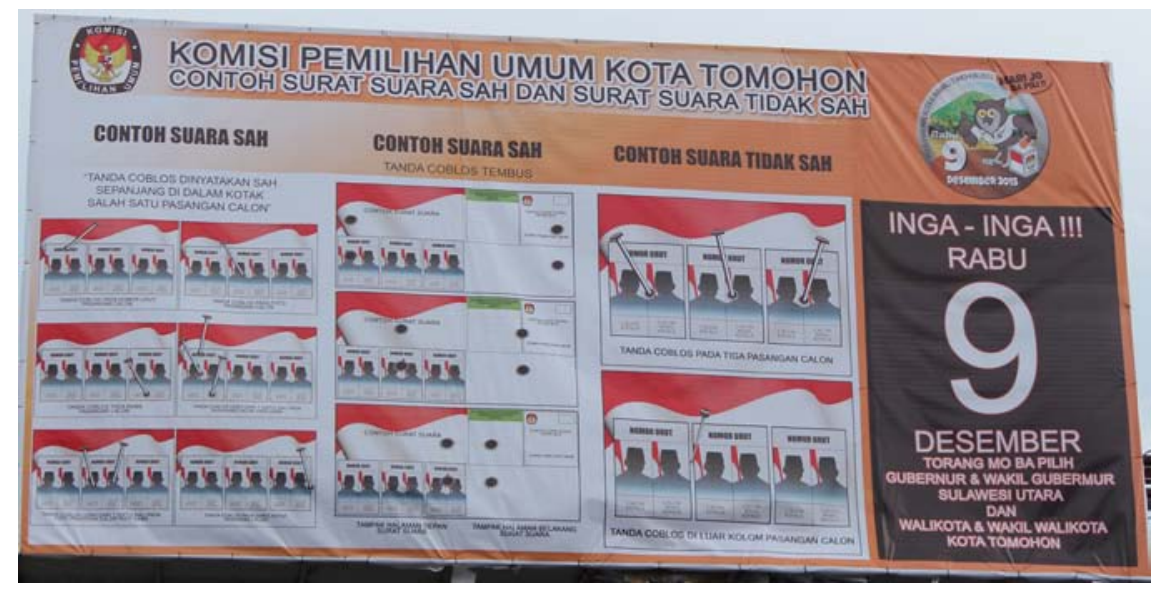

FIGURE 5 Authorizing localness

Figure 1, we can also infer that PDI-P is a well-funded political party as it is capable of funding large, glossy, colour billboards.

But even more interesting is the campaign slogan Jonru adalah torang (Jonru is us), which can be seen in the top left hand corner. This slogan uses a mix of two language varieties, including the Indonesian copula adalah and the Manado Malay ( $\mathrm{MM}$ ) first-person inclusive pronoun torang (we). It is interesting, because this mixing helps select two audiences: those who can read Manado Malay and those who can read Indonesian. From a syntactic perspective the script is Indonesian, because м $\mathrm{M}$ lacks the copula adalah, but the emphasis placed on the M M pronoun torang (it is in larger font and bold) suggests that $\mathrm{MM}$, the language of everyday spoken communication in multi-ethnic settings, sits above Indonesian in the language hierarchy in the imaginations of the sign producers.

It is also useful to point out the connections between PDI-P and its constituents who, in Java at least, were often from low-income households and had less access to 'standard Indonesian'. This inscription thus invites at least two sets of readers. The first set is comprised of those who see the candidates as like them by way of their ability to apparently use language in a similar way. The second set comprises those who have access to Indonesian and the privileges associated with Indonesian. Like figures 2 and 3 , Figure 4 is also an example of latent enfranchisement because $\mathrm{MM}$ is not the language of schooling, although it can be found in most other social domains.

Figure 5 is a picture of a billboard located on the main street in Tomohon. Jukes took this picture in November 2015. Rather than being authorized and designed by a political party, this billboard was designed and authorized by the 
Komisi Pemilihan Umum Kota Tomohon 'Tomohon Electoral Commission' and gives examples of valid (sah) and invalid (tidak sah) votes.

The sign in Figure 5 is interesting because it suggests that the place of MM in the local language hierarchy is not just something imagined by one political party and the producers of signs, but something also recognized by the local government. Although the bulk of the 'how to vote' instructions on this poster are in Indonesian (suggesting Indonesian sits above $\mathrm{m} \mathrm{M}$ in the local linguistic hierarchy imagined by the sign producers), the prominent black section on the right reminds people to vote in M M: Inga-inga!!! Rabu g Desember torang mo ba pilih Gubernur dan Wakil Gubernur Sulawesi Utara dan Walikota dan Wakil Walikota Kota Tomohon (Remember!!! On Wednesday 9 December we will choose the governor and deputy governor of North Sulawesi and the mayor and deputy mayor of Tomohon City).

As with Figure 4, there is no Indonesian translation, which suggests that the electoral commission regards $\mathrm{MM}$ as an important vehicle for transmitting messages. When compared with figures 2 and 3 we also see that the placement of languages in Figure 5 models the idea of the existence of two separate, unmixed languages- $-\mathrm{MM}$ and Indonesian. While this confirms what we know about the diminishing authority of the nation-state to enforce the use of just one language for communication with a wider audience (in the past this was Indonesian), the attention paid to contemporary signage provides us with insights into whether and to what extent this trend continues.

Figure 6 is from a later stage of the same campaign, as described in our discussion of Figure 4. It was taken by Jukes in Tomohon in November 2015. Vonny Jane Paat, or 'vop', had emerged as Jonru's running mate, so the campaign slogan was changed to Jonru VOP adalah torang. The notable thing about this poster is that they have added a slogan in Tombulu, the indigenous language of the area surrounding Tomohon.

The slogan (on the bottom left) reads Pah'wali-walian wangen Umbanua Tou Muung (Working together to build Tomohon City). As can be seen, the Tombulu text is very small and includes a translation (on the bottom right) into standard Indonesian: Bersama \& bersama-sama membangun Kota Tomohon. According to the Tombulu speakers Jukes polled, the translation is not quite accurate. This could be due to the fact that translating from Tombulu directly into Indonesian rather than into Manado Malay is considered somewhat artificial, or, as some speakers have said, kurang enak ('doesn't feel right'; literally, 'not tasty').

The use of Tombulu ostensibly widens the audience by also selecting an older demographic. However, the placement and size of the text in Tombulu relative to $\mathrm{MM}$ also tells us something about the size of this demographic 


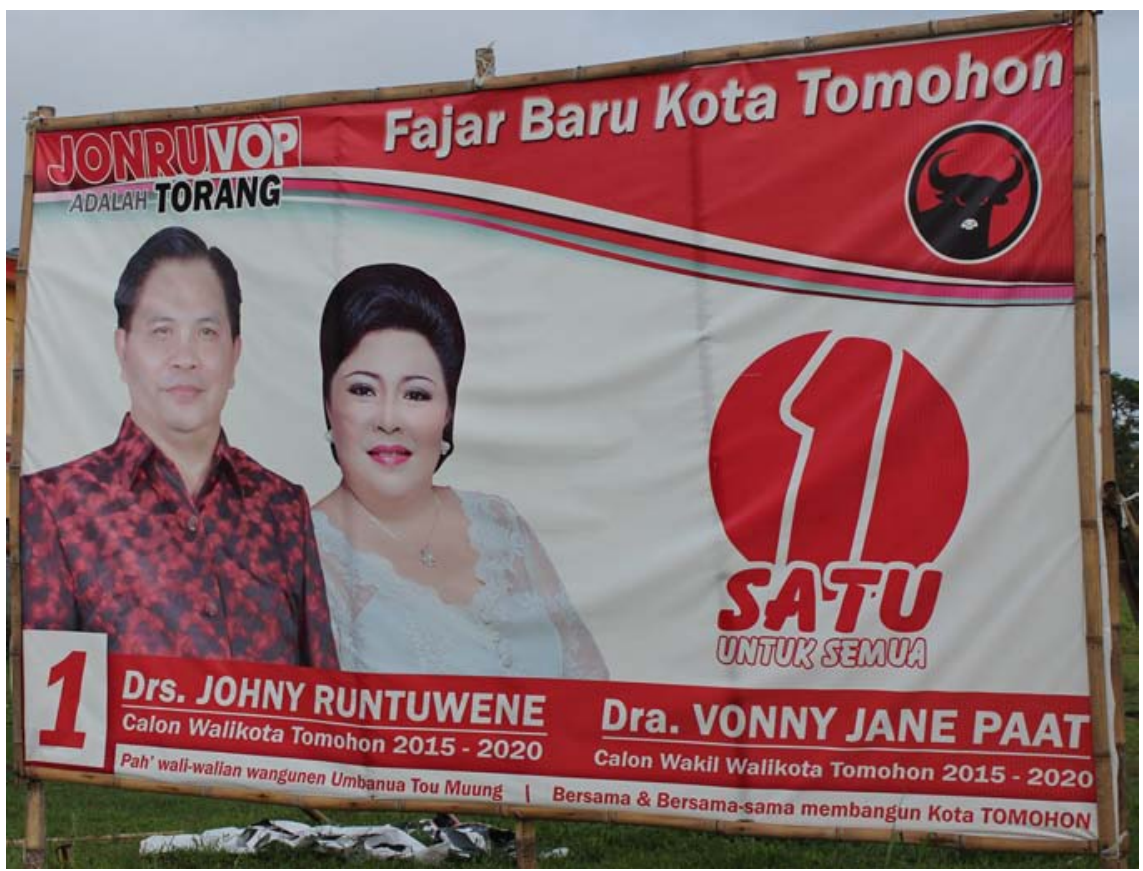

FIGURE 6 Selecting an older audience by paying lip service to local languages

and where Tombulu sits in the local language hierarchies. Work on language endangerment tells us that Tombulu can be considered endangered because few children learn it, even in rural areas outside of Tomohon, while in Tomohon itself Tombulu has long fallen out of daily use (Renwarin, 2006:35). While it appears to be important to include Tombulu for its symbolic value in an era when demonstrating some form of localness is important, it appears to be perceived by the principle (the authorizer(s) of this sign) as having little communicative value. This is indicated by the extremely small text and the presumed need for an Indonesian translation, something that we do not find in signs containing MM.

Local/regional languages, or bahasa daerah, have long been considered important in Indonesia. They are recognized as important in the 1945 Indonesian constitution (Nababan, 1985, 1991); they were introduced into the education curriculum on the national level in 1994; and their importance continues as decentralization legislation has supported local-language content in the curriculum (Kurniasih, 2016), which in some cases has helped to enfranchise languages in other parts of Sulawesi (Sudarkam Mertono, 2014). Even so, Tombulu can only marginally be considered a language of latent enfranchisement, because it is not taught in local schools nor used in many social contexts, 
as is the case for languages like PM and MM. In a sense, it is a casualty of nationbuilding exercises, as are other marginal minority languages.

Finally, it should be pointed out that all of the provincial and district level laws mentioned thus far are highly likely to be reinforced by the current local language bill, ${ }^{7}$ which is expected to be rubber-stamped (that is, passed) by the Dewan Perwakilan Daerah 'Indonesian National Parliament' as a law in 2017. This may provide further impetus for other instances of latent enfranchisement throughout the archipelago.

\section{Conclusion}

In this article we have introduced the concept of linguistic enfranchisement as a tool for gaining insights into social change. We have defined linguistic enfranchisement as a process, a product, and as an object of nation-building activities. We have distinguished two types of enfranchisement-linguistic and latent - with the latter category being used for situations where there has been no use of a local language as a language of schooling, or as a subject within the school curriculum. We have drawn on a wide range of sociolinguistic research, especially on work that focuses on linguistic landscapes and ideas around the semiotics of materiality, to focus on the street signage used for political campaigns from three areas of Indonesia: West Java, Papua, and North Sulawesi. We have shown how giving attention to the placement and size of fragments of language can provide insight into levels of linguistic enfranchisement; local language hierarchies; the extent to which the nation-state is able to impose its well-known ideology of one nation, one people, one language; the extent to which the nation-state authorizes the use of particular languages; and the relationship of these phenomena with different levels of government. For example, in Papua we saw that the situation of Papuan Malay could be interpreted as one of latent enfranchisement. We also pointed out that language mixing was authorized on various levels: that of the province, city, and village.

While local indigenous languages, such as Sundanese and Tombulu, have a long history of authorization vis-à-vis their acknowledged importance in the Indonesian constitution, the increase in their respective social values is

7 This bill, Rancangan uU Republik Indonesia no. ... /2016? tentang Bahasa Daerah 'Constitutional Bill of the Republic of Indonesia, number ... /2016 concerning regional languages' was slated to be discussed in 2016, but was still awaiting consideration from the Indonesian National Parliament at the end of January 2017. 
a much more recent phenomenon. Of all the languages discussed here, Sundanese has the strongest history of authorization. In addition to the recent regulations about Sundanese cited above, this history includes the publication of novels, newspapers, and printed material; radio and television broadcasts; and inclusion in the classroom curriculum (Goebel, 2015, 2016; Moriyama, 2005, 2012). Even though the effectiveness of the delivery of the local language curriculum has been patchy (Bjork, 2005; Kurniasih, 2007), the fact that Sundanese is offered as a school subject points to the linguistic enfranchisement of Sundanese and Sundanese speakers at the provincial and district levels.

Papuan Malay has a strong history, too, but it has yet to be offered as the language of schooling. This reduces the possibility of the existence of large audiences that have the ability to recognize PM, and thus respond to the type of invitations found in Figure 1. Even so, PM is emerging in a number of political domains, and this is an indicator of ongoing change on both the provincial and district/city levels, while also pointing to future enfranchising possibilities. Although Manado Malay was never a language of schooling, its usage in signage tells us that there is increasing recognition of its status as the default (albeit unofficial) language of the province. Its increasing use in slogans and official signage shows that MM has both a symbolic value, through appealing to the Manadonese/Minahasan identity, and a practical value as the most widely understood language of the region.

To conclude, a few points about future directions are in order. First, through a comparison of signage in three very different areas of Indonesia we have shown that representations of language hierarchy are not limited to one place or to the imagery of one political party and those who produce signage for them. This change in signage practices has a long history of support, at least at the policy level, from the national, provincial, and district level governments. Imitation and uptake are important parts of the overall argument because, as linguistic anthropologists with keen interests in semiotics have reminded us (Agha, 2007; Keane, 2003), a sign does not become a sign unless it is recognized and imitated by someone. That is, such configurations become part of a person's semiotic ideology (Keane, 2003). The imitation of the semiotic configuration of signage in different parts of Indonesia tells us that particular semiotic ideologies that value local languages were recognized by segments of the population and that they also had some uptake, at least by those who are involved in the production of political signage.

Second, it seems important to understand whether and to what extent either Manado Malay or Papuan Malay are found in other social domains, such as television and radio. This is so because the marketization of regional 
languages on television in the early 1990 s increased the visibility and value of these previously marginalized languages, especially in Java (Goebel, 2015; Kitley, 2000; Loven, 2008; Sen \& Hill, 2000). The avalanche of imitations of local content on Indonesian television from this time on-as part of efforts to gain and maintain market share-continued to increase the social value of these languages in a way akin to the goal of early nation-building activities, where creating pride in the nation was partly achieved via creating pride in a language (e.g. Heller \& Duchêne, 2012a; Hobsbawm, 1992).

Third, to what extent might further enfranchisement of MM and PM create inequality within the sites described here? For example, if MM were to become the language of instruction in schools in Manado, then what impact would this have on migrants who don't speak MM? Fourth, our strengths in being able to read fragments of multiple languages and being able to work with contemporary theory in sociolinguistics and linguistic anthropology comes at the cost of not being on top of progress in the areas of education or political science. To us, at least, this signals an opportunity for inter-disciplinary collaboration between sociolinguists, area studies language specialists, and those working in the fields of education and political science.

A number of interesting possibilities come to mind. The first is driven by the potentials of 'unrealized signs' (Keane, 2003: 414) and the multiple potential audiences selected by the semiotic configuration we have referred to as signage. For example, to what extent might the emphasis on political figures rather than policy relate to patron-client relationships? Does the type of signage we have examined project potential new patrons? How do passers-by interpret this signage? Taking inspiration from Loven's (2008) work on the production of television serials, another equally interesting area for future work could be an examination of the complex interactions that lie behind the production of political campaign signage. For example, how do political parties, candidates, marketers, text designers, media production houses, and campaign supporters work together to draft, edit, produce, and place signage, and how might this relate to linguistic enfranchisement? How does this compare with past practices, such as those found in the 1997 election campaign, when signage consisted of banners with symbols and little text? Finally, placing greater emphasis on local language policies as they relate to local content within schools, together with linguistically sensitive ethnographic accounts of the uptake of these policies, could also help us understand whether latent enfranchisement is developing into linguistic enfranchisement. 


\section{References}

Agha, A. (2007). Language and social relations. Cambridge: Cambridge University Press.

Aspinall, E. (2011). Democratization and ethnic politics in Indonesia: nine thesis. Journal of East Asian Studies, 11, 289-319.

Aspinall, E., \& Mietzner, M. (Eds.). (2010). Problems of democratisation in Indonesia: elections, institutions and society. Singapore: ISEAS.

Barth, F. (Ed.) (1969). Ethnic groups and boundaries: the social organization of cultural difference. Bergen: Universitets Forlaget.

Bjork, C. (2005). Indonesian education: Teachers, schools, and central bureaucracy. New York: Routledge.

Blommaert, J. (2010). The sociolinguistics of globalization. Cambridge: Cambridge University Press.

Blommaert, J. (2013). Ethnography, superdiversity and linguistic landscapes: chronicles of complexity. Bristol: Multilingual Matters.

Bourdieu, P. (1984). Distinction: a social critique of the judgement of taste. Cambridge, Massachusetts: Harvard University Press.

Bourdieu, P. (1991). Language and symbolic power. Cambridge: Polity Press in association with Basil Blackwell.

Bourdieu, P., \& Passeron, J.-C. (1977). Reproduction in education, society and culture. London: Sage.

Bucholtz, M. (1999). "Why be normal?": Language and identity practices in a community of nerd girls. Language in Society, 28(2), 203-223.

Bünte, M., \& Ufen, A. (Eds.).(20o9). Democratization in Post-Suharto Indonesia. London: Routledge.

Cole, D. (2016). The material force of signs and the reconfigurement of superdiverse identities. In Z. Goebel, D. Cole, \& H. Manns (Eds.), Margins, hubs, and peripheries in a decentralizing Indonesia (pp. 112-125). Tilburg Papers in Culture Studies, special issue number 162 .

Cope, B., \& Kalantzis, M. (Eds.). (200o). Multiliteracies: Literacy learning and the design of social futures. South Yarra, Vic.: Macmillan.

Dardjowidjojo, S. (1998). Strategies for a successful national language policy: The Indonesian case. International Journal of the Sociology of Language, 130, 35-47.

Davidson, J., \& Henley, D. (Eds.). (2007). The revival of tradition in Indonesian politics: the deployment of adat from colonialism to indigenism. London: Routledge.

Djenar, D.N. (2016). Adolescent interaction in fiction and peripheralisation of languages. In Z. Goebel, D. Cole, \& H. Manns (Eds.), Margins, hubs, and peripheries in a decentralizing Indonesia (pp. 42-50). Tilburg Papers in Culture Studies, special issue number 162. 
Donzelli, A. (2016). Transnational neoliberal democracy and the vintage aesthetics of the margins in Post-Suharto political oratory. In Z. Goebel, D. Cole, \& H. Manns (Eds.), Margins, hubs, and peripheries in a decentralizing Indonesia (pp. 77-100). Tilburg Papers in Culture Studies, special issue number 162.

Eckert, P. (2000). Linguistic variation as social practice: The linguistic construction of identity in Belten High. Oxford: Blackwell.

Errington, J. (1998). Shifting languages: Interaction and identity in Javanese Indonesia. Cambridge: Cambridge University Press.

Gal, S. (2012). Sociolinguistic regimes and the management of "diversity". In M. Heller \& A. Duchene (Eds.), Language in late capitalism: pride and profit (pp. 22-42). Hoboken: Routledge.

Goebel, Z. (2008). Enregistering, authorizing and denaturalizing identity in Indonesia. Journal of Linguistic Anthropology, 18(1), 46-61.

Goebel, Z. (2015). Language and superdiversity: Indonesians knowledging at home and abroad. New York: Oxford University Press.

Goebel, Z. (2016). Infrastructures for ethnicity: understanding the diversification of contemporary Indonesia. Asian Ethnicity. Retrieved from doi:10.1080/14631369.2016 .1146985 (accessed 20-02-2016)

Goebel, Z., Cole, D., \& Manns, H. (Eds.). (2016). Margins, hubs, and peripheries in a decentralizing Indonesia: Tilburg Papers in Culture Studies, special issue 162.

Goffman, E. (1981). Forms of talk. Philadelphia: University of Pennsylvania Press.

Hariyadi, Shodiq, D., \& Restuadhi, H. (2015). Creative youth and the government: how young creative entrepreneurs respond to the government's handling of creative economies in Purwokerto. Paper presented at the Indonesia Open Council Conference, Deakin University, Geelong, 2-3 July.

Harr, A. (2016). Recentering the margins? The politics of local language in a decentralizing Indonesia. In Z. Goebel, D. Cole, \& H. Manns (Eds.), Margins, hubs, and peripheries in a decentralizing Indonesia (pp. 70-76). Tilburg Papers in Culture Studies, special issue number 162 .

Hedman, E.-L. (Ed.) (2008). Conflict, violence, and displacement in Indonesia. Ithaca, N.Y.: Cornell University.

Heller, M. (2011). Paths to post-nationalism: a critical ethnography of language and identity. New York: Oxford University Press.

Heller, M., Bell, L., Daveluy, M., McLaughlin, M., \& Noel, H. (2015). Sustaining the nation: the making and moving of language and nation. New York: Oxford University Press.

Heller, M., \& Duchêne, A. (2012a). Pride and profit: changing discourses of language, capital and nation state. In M. Heller \& A. Duchene (Eds.), Language in late capitalism: pride and profit (pp. 1-21). Hoboken: Routledge.

Heller, M., \& Duchêne, A. (Eds.). (2012b). Language in late capitalism: pride and profit. Hoboken: Routledge. 
Heller, M., Pujolar, J., \& Duchêne, A. (2014). Linguistic commodification in tourism. Journal of Sociolinguistics, 18(4), 539-566.

Henley, D., \& Davidson, J. (2007). Introduction: radical conservatism - the protean politics of adat. In J. Davidson \& D. Henley (Eds.), The revival of tradition in Indonesian politics: The deployment of adat from colonialism to indigenism (pp. 1-49). London: Routledge.

Hobsbawm, E. (1992). Nations and nationalism since 1780:programme, myth, reality (2nd Ed.). Cambridge: Cambridge University Press.

Inoue, M. (2006). Vicarious language: gender and linguistic modernity in Japan. Berkeley: University of California Press.

Jukes, A. (2010). Someone else's job: externalizing responsibility for language maintenance. Paper presented at the fourteenth foundation for endangered language conference: reversing language shift: how to re-awaken a language tradition, $13-15$ September, Carmarthen, Wales.

Keane, W. (1999). The materiality and locality of everyday lives. Indonesia, 68 (October), 178-186.

Keane, W. (2003). Semiotics and the social analysis of materail things. Language and Communication, 23(3-4), 409-425.

Kitley, P. (200o). Television, nation, and culture in Indonesia. Athens: Ohio University Press.

Kuipers, J. (1998). Language, identity and marginality in Indonesia: the changing nature of ritual speech on the island of Sumba. Cambridge: Cambridge University Press.

Kurniasih, Y. (2007). Local content curriculum 1994: The teaching of Javanese in Yogyakarta schools. Paper presented at the First International Symposium on the Languages of Java (IS LOJ), 15-16 August, Graha Santika Hotel, Semarang, Indonesia.

Kurniasih, Y. (2016). Local activism versus recentralization: The case of Javanese in municipal offices in Central Java. In Z. Goebel, D. Cole, \& H. Manns (Eds.), Margins, hubs, and peripheries in a decentralizing Indonesia (pp. 137-147). Tilburg Papers in Culture Studies, special issue number 162.

Loven, K. (2008). Watching Si Doel: television, language, and cultural identity in contemporary Indonesia. Leiden: KITLV Press.

Menteri Dalam Negeri [Domestic Affairs Ministry]. (2007). Peraturan menteri dalam negeri nomor 40 tahun 2007: pedoman bagi kepala daerah dalam pelestarian dan pengembangan bahasa negara dan bahasa daerah [Internal Minestry Law number 40, 2007: guidelines for district heads about the preservation and development of the national language and regional languages. Jakarta.

Moore, R. (2011). Standardisation, diversity and enlightenment in the contemporary crisis of E U language policy. Working Papers in Urban Language and Literacies, 74, 1-31.

Morin, I. (2016). Marginalizing and revaluing Papuan Malay: The impact of politics, policy and technology in Indonesia. In Z. Goebel, D. Cole, \& H. Manns (Eds.), 
Margins, hubs, and peripheries in a decentralizing Indonesia (pp. 101-111). Tilburg Papers in Culture Studies, special issue number 162.

Moriyama, M. (2005). Sundanese print culture and modernity in nineteenth-century West Java. Singapore: Nus Press.

Moriyama, M. (2012). Regional languages and decentralization in post-New Order Indonesia: the case of Sundanese. In K. Foulcher, M. Moriyama, \& M. Budiman (Eds.), Words in motion: language and discourse in post-New Order Indonesia (pp. 82-100). Tokyo: Research Institute for Languages and Cultures of Asia and Africa, Tokyo University of Foreign Studies.

Nababan, P.W.J. (1985). Bilingualism in Indonesia: Ethnic language maintenance and the spread of the national language. Southeast Asian Journal of Social Science, 13(1), 1-18.

Nababan, P.W.J. (1991). Language in education: The case of Indonesia. International Review of Education, 37(1), 113-131.

Pietikäinen, S., \& Kelly-Holmes, H. (Eds.). (2013). Multilingualism and the Periphery. New York: Oxford University Press.

Rachmah, I. (2006). Watching Indonesian sinetron: imagining communities around the television. Department of media and information, Curtin University, PhD Perth.

Rampton, B. (1995). Crossing: language and ethnicity among adolescents. London: Longman.

Rampton, B. (2006). Language in late modernity: Interaction in an urban school. Cambridge: Cambridge University Press.

Rampton, B. (2011). From 'Multi-ethnic adolescent heteroglossia' to 'Contemporary urban vernaculars'. Language \& Communication, 31(4), 276-294.

Renwarin, P.R. (2006). Matuari and Tona'as: The Cultural Dynamics of the Tombulu in Minahasa. Department of Anthropology, Leiden University, PhD Leiden.

Rutherford, D. (2003). Raiding the land of the foreigners: the limits of the nation on an Indonesian frontier. Princeton, NJ: Princeton University Press.

Scollon, R., \& Scollon, S.W. (2003). Discourses in place: Language in the material world. London: Routledge.

Sen, K., \& Hill, D.T. (200o). Media, culture and politics in Indonesia. Oxford: Oxford University Press.

Stroud, C., \& Mpendukana, S. (2009). Towards a material ethnography of linguistic landscape: Multilingualism, mobility and space in a South African township. Journal of Sociolinguistics, 13(3), 363-386.

Sudarkam Mertono. (2014). The decentralization of schooling in Palu, Central Sulawesi, Indonesia. PhD dissertion. Department of Asian Studies, La Trobe University, Melbourne.

Urban, G. (2001). Metaculture: how culture moves through the world. Minneapolis, MN: University of Minnesota Press. 